\title{
INFLUENCE EMPLOYMENT BY IMPROVING AEROBICS ON MOTOR READINESS OF GIRLS
}

Shypulo I. P.

Chernihiv National Pedagogical University

Annotation. Purpose: substantiate the effect of employment by improving aerobics on motor readiness of girls in extracurricular educational institutions. Material: the study involved 90 women aged 16-18 years old. Classes are held 3 times a week for 1 hour each. Results: defined state and the most informative indicators motor fitness girls. Built analytical model of graph model for forecasting and conducting quantitative and qualitative control of motor fitness girls. The degree of severity of each of the parameters studied motor fitness girls. Conclusions: the possibilities of predicting outcomes. Recommended method of aerobics classes, which has five stages. Its main feature - the constant objective control efficiency of employment.

Keywords: classes, aerobics, motion, training, girls.

\section{Introduction}

Worsening of health and insufficient motion fitness of school age children is undoubtedly a serious problem [15]. That is why, at present, one of main tasks is control of strengthening of youth's health, formation of their demand in motion perfection and healthy life style.

Unfortunately, as on to day traditional physical culture lesson ensures, in average, up to $11 \%$ of required weekly motion functioning; about $50 \%$ of children have no steady interest to physical culture [5]. Most of specialists think that accent on increasing of physical culture-physical education work shall be realized in out of school forms of trainings.

Hat is why at present there is active implementation of innovative methodic in out of school educational establishments in order to achieve and maintain children's optimal physical condition, their motivation and individual features $[1,2,14]$.

These problems were reflected in Conception of out of school education and learning, in Laws of Ukraine "On education", "On physical culture and sports", in National doctrine of development of education, in National doctrine of physical culture and sports development, in decree of Council of Ministries of Ukraine "On approval of nomenclature of national educational establishments' types; principles of out of school educational establishments and National strategy of development of education in Ukraine for 2011-2016. The state ensures creation of all conditions for children's involvement in sports and motion functioning.

It is known that just motion fitness influences substantially on physical condition of a person. For example, it can improve health and mental state of a person (reduce risk of many diseases, strengthen "life tonus", activity and workability, regulate organism's functioning, improve mood, everyday self-feeling and so on). It improves physical condition (increases strength and endurance, flexibility and coordination); it improves posture (reduces quantity of fat, increase or reduce volume of muscles and etc.). Alongside with it motion fitness is interpreted as result of comprehensive development of motion abilities, functional potentials of organism's organs and systems, their coordination in process of muscular functioning $[6,9,15,20]$.

Analysis of health related practices witnesses that among girls one of the most popular kinds of health related physical culture is aerobic. Analysis of scientific methodic literature showed that high health related effect is reached exactly with aerobics' exercises $[3,5,11,12]$.

As on to day there have been researched and worked out great number of methodic and programs of aerobics' traininga [4, 7, 8, 10, 13, 16-19]; but the problem of demand in aerobics' trainings of 16-18 years old girls in out of school educational establishments has been still remaining urgent and insufficiently studied.

The work has been fulfilled in compliance with priority direction of scientific researches of Chernigov national pedagogic university, named after T.G. Shevchenko: Didactic principles of motion functions' formation of persons, practicing physical culture and sports", (state registration number 0108U000854, dt. February 19 $9^{\text {th }}, 2008$ ), "Pedagogic ways of formation of healthy life style of different age groups' schoolchildren" (state registration number $0112 \mathrm{U} 001072$ dt. 18.01.2012).

Purpose, tasks of the work, material and methods

The purpose of the work is to analyze influence of health related aerobics' trainings on girls' motion fitness in out of school educational establishments.

The research was conducted on the base of methodic center of vocational training in Chernigov region and in Regional public organization "Federation of aerobics of Chernigovschina", Federation of aerobics in Odessa, studio of dance and aerobics "VerDikt", dancing center " 5 th element" and on the base of Chernigov national pedagogic university, named after T.G. Schevchenko.

For solution of our tasks, in academic health related process on aerobics at out of school educational establishment we introduce and carried out forming pedagogic experiment (we created experimental and control groups). Experimental (EG) group of girls was trained by offered by us methodic, control group (CG) - by traditional.

\footnotetext{
(C) Shypulo I. P., 2015

http://dx.doi.org/10.15561/20755279.2015.0110
} 
Trainings were conducted trice a week; 1 hour every training. Total scope and intensity of loads in both groups were equal. Trainings in CG were conducted in compliance with recommendations $[4,8,10]$.

The worked out by us structure of process of girls' motion development at aerobics' trainings at out of school educational establishments included: purpose; certain tasks, model indicators of development of motion abilities, health and motion progress; principles; control; scope of load; forms of trainings' organization; methods; system of pedagogic influences; practical application; health related result.

Exactly methodic of aerobic training of girls at out of school educational establishments includes five stages, which differ by particular tasks and purposes.

We conducted the following tests: 1 - long jump, cm; 2- "Shuttle run", sec.; 3- chin ups, q-ty of times; 4pressing ups in lying position, q-ty of times; 5 - taking sitting position from lying one (during 1 minute); 6- hanging on bent arms, sec.; 7- forward torso bending, cm; 8- dynamometry of backbone, $\mathrm{kg}$.

Testing was fulfilled at the beginning and at the end of experiment. Experiment lasted for three years.

Results of the research

Research of girls' (who train aerobics) motion fitness is very important for practice of training and education of rising generation. Exactly such researches permit to reveal all problems at aerobics' trainings and in changing of girls' individual abilities under influence of trainings, as well as to reveal motivation and interest to trainings.

By results of tests we determined girls' motion fitness in special health group (SHG) and in sport group (SG). example:

We found that in SHG, in comparison with SG (see fig.1) indicators of motion fitness were much worse. For

- In long running jump SHG girls' indicators: $121.30 \pm 5.17 \mathrm{~cm}$ and $198.52 \pm 7.28 \mathrm{~cm}$;

- In "Shuttle run": $16.84 \pm 1.43 \mathrm{sec}$. and $10.55 \pm 1.04 \mathrm{~min}$.;

-In chin ups, SHG groups' girls had $2.58 \pm 0.27$ times and 5.04 \pm 0.51 timers;

- In pressing ups in lying position SHG indicators were 16.77 \pm 1.71 times and in SG $30.53 \pm 3.15$ times;

- Taking sitting position from lying one (during 1 minute) in SHG - 23.52 \pm 2.42 times and in SG - 45.00 \pm 3.94 times;

- Indicators of hanging on bent arms in SHG were 22.28 $\pm 2.51 \mathrm{sec}$. and in SG - 41.68 $\pm 4.31 \mathrm{sec}$;

- Indicators of forward torso bending in SHG were $13.93 \pm 1.41 \mathrm{~cm}$ and $26.68 \pm 2.70 \mathrm{~cm}$;

- Indicators of backbone dynamometry were in SHG $32.79 \pm 3.34 \mathrm{~kg}$ and in SG - $59.74 \pm 6.10 \mathrm{~kg}$.

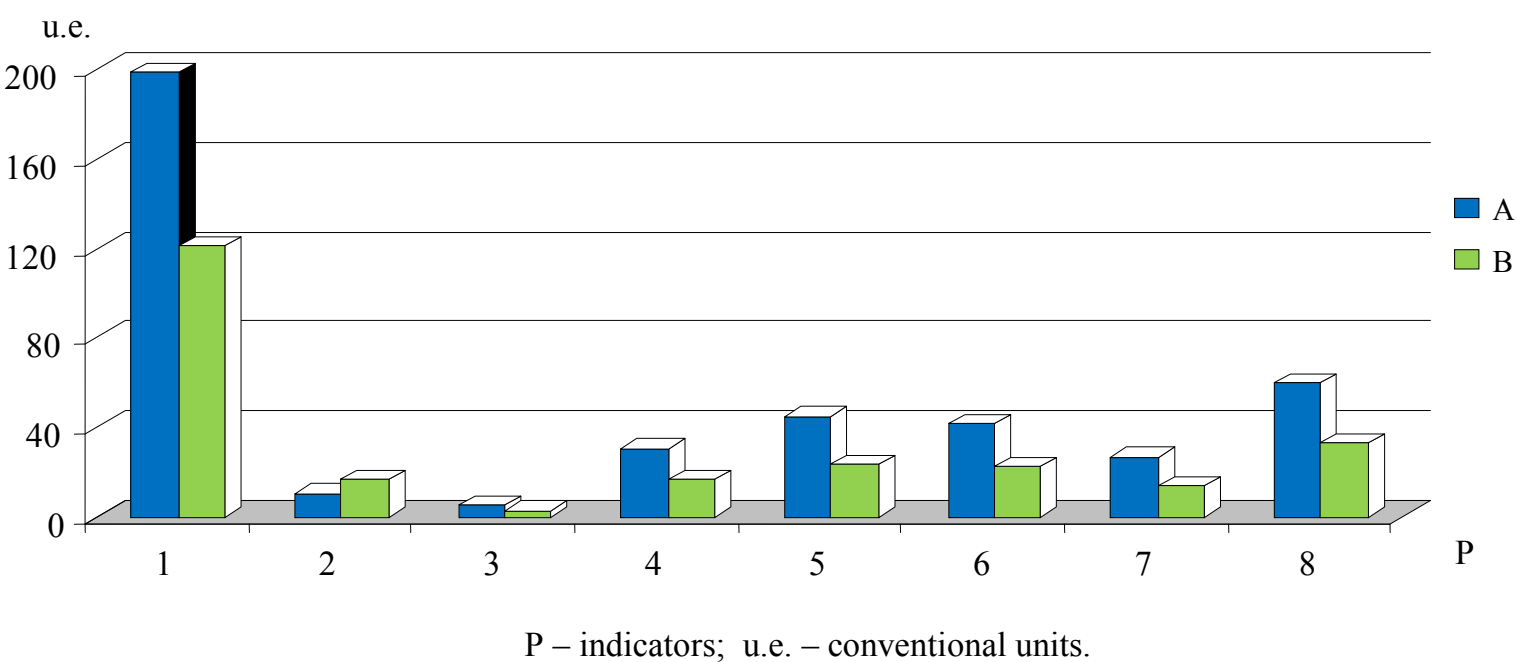

Fig. 1. Mean statistical results of motion fitness of SHG (A) $S G(B)$ girls:

1 - long jump, cm; 2 - "Shuttle run", sec.; 3 - Chin ups, q-ty of times; 4 - Pressing ups in lying position, q-ty of times; 5 - Taking sitting position from lying one (during 1 minute); 6 - Hanging on bent arms, sec.; 7 - Forward torsi bending, $\mathrm{cm} ; 8$ - Back dynamometry, $\mathrm{kg}$.

It was determined that girls of sport group had better motion fitness. The received data permit to rather objectively prognosticate results with purposeful, comprehensive girls' trainings of aerobics.

Correlation analysis permitted to determine the most informative girls' indicators. The received indicators are interconnected and influence on girls' physical fitness.

On the base of the obtained data we built graphic analytic model for quantitative and qualitative control, which also permits to prognosticate development of girls' motion fitness (see fig.2). 


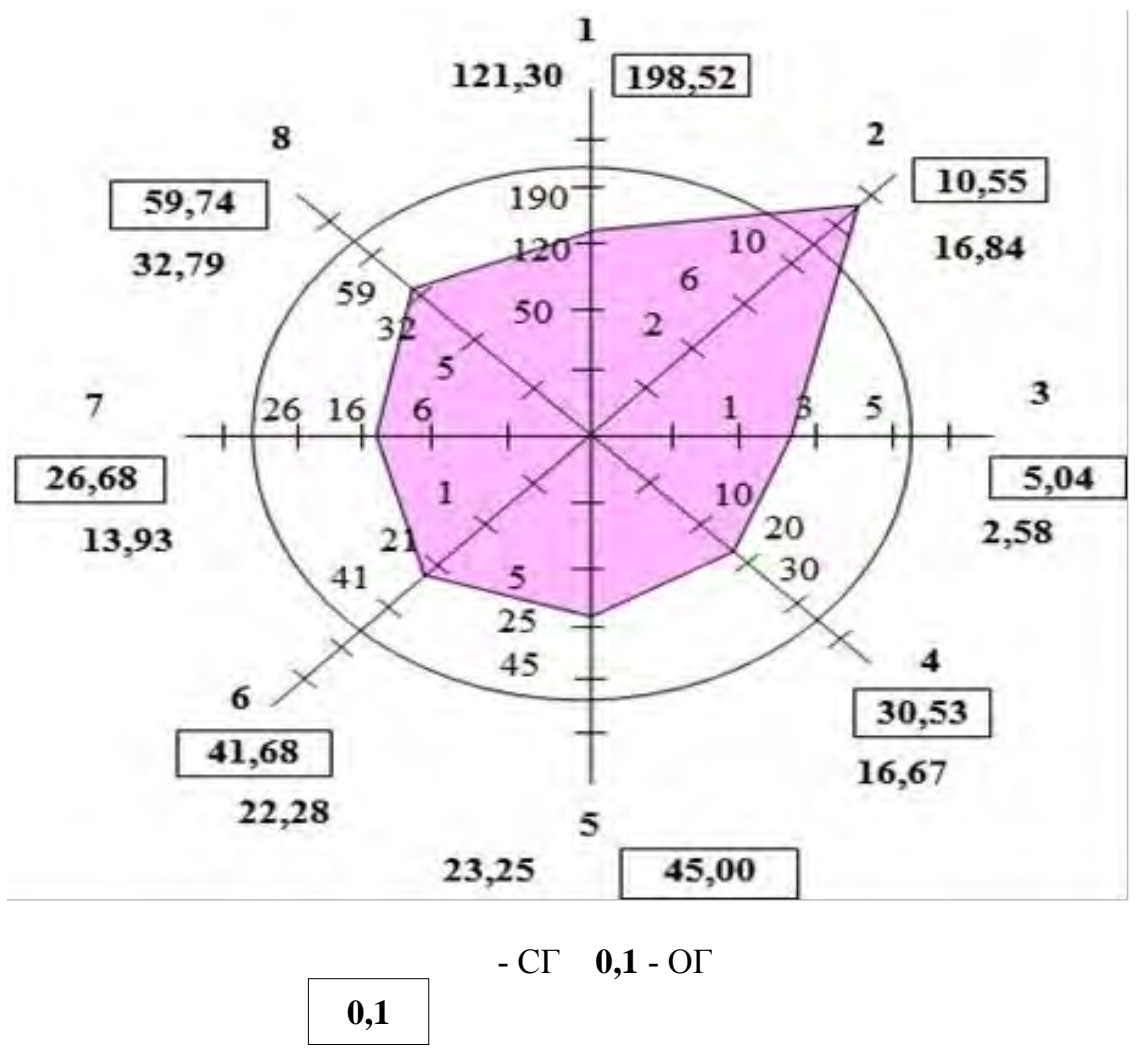

Fig.2. Graphic analytical model of motion fitness of health related (SHG) group's girls and sport group's (SG) girls: 1 - shuttle run; 2 - forward torso bending; 3 - taking sitting position from lying one during 1 minute; 4 - backbone dynamometry (torso); 5 - long jump; 6 - chin ups; 7 - hanging on bent arms; 8 - pressing ups in lying position.

Analysis of aerobic trainings' influence on girls' motion fitness showed that in EG it improved by $37 \%$, and in $\mathrm{CG}-$ by $23 \%$ (see fig. 3 ).



P -indicators; u.e. - conventional units.

Fig.3. Comparison of motion fitness of experimental group's girls (C) and control group's girl (D).

1 - shuttle run; 2 - forward torso bending; 3 - taking sitting position from lying one during 1 minute; 4 - backbone dynamometry (torso); 5 - long jump; 6 - chin ups; 7 - hanging on bent arms; 8 - pressing ups in lying position.

The received EG indicators are much better than indicators of $\mathrm{CG}$ and witness that introduction of experimental methodic was rather useful.

\section{Discussion}

In the whole, in context of improvement of girls' motion fitness our data are accorded quite satisfactory with ideas of other authors $[4,7,8,10,13,16-19]$. Alongside with it approaches, recommended by us, differ a little from commonly accepted by the following:

- complex approach to application of aerobics for comprehensive girls' development;

- at aerobics' trainings we used new and variable means and methods; 
- development of girls' motion skills was realized with accurate dozing of loads' parameter and their control at every training;

- realization of health, functional state and motion fitness control контроль took place at every training, every week, every month for determination of loads' parameters and diagnostic of dynamic of indicators' change;

- in power part of every training we paid attention to development of legs', arms' and torso muscles; and etc.;

- we also paid attention to perfection of coordination, videlicet: dexterity, jumping ability, balance, rhythm

- in warming up and final parts of every training we paid attention to flexibility;

- trainings were conducted with application of aerobics' health related exercises, which were based on prognostic graphic analytical models;

- for evaluation of initial data of girls' motion fitness we used bio-mechanical indicators except generally accepted characteristics; monitoring.

- correction of girls' motion fitness at aerobics' trainings was realized on the base bio-mechanical

In general results of pedagogic experiment completely prove our opinion about solution of increasing of girls' motion fitness at out of school educational establishments.

Conclusions:

1. Testing of effectiveness of pedagogic experiment showed that purposeful education-learning process of health related aerobics improves girls' motion fitness.

2. The received indicators of girls' motion fitness are maximally close to model indicators.

3. Application of the newest means and methods will vary aerobics' trainings of 16-18 years' old girls.

\section{References:}

1. Bulatova M.M. Fitnes i dvigatel'naia aktivnost': problemy i puti resheniia [Fitness and physical activity: problems and decision ways]. Teoriia i metodika fizicheskogo vospitaniia i sporta, 2007, no.1, pp. 3-7. (in Russian)

2. Zinchenko V.B., Usachev Iu.A. Fitnes-tekhnologii v fizicheskom vospitanii [Fitness technology in physical education], Kiev, NAU, 2011, 152 p. (in Russian)

3. Ivlev M.P. Soderzhanie i metodika zaniatij ritmicheskoj gimnastikoj s zhenshchinami zrelogo vozrasta. Kand.dis. [Content and methodology of employment by rhythmic gymnastics with women of mature age. Kand.dis.], Moscow, 1987, 23 p. (in Russian)

4. Krivoruchko S.N., Panasejko Iu.G., Belous N.S. Aerobika na zaniatiiakh po fizicheskom vospitaniiu [Aerobics on physical education classes], Kharkov, KHAI, 2012, 56 p. (in Russian)

5. Krucevich T.Iu., Bezverkhniaia G.V. [Formation of motivation in physical education and sport at school age]. Olimpijskij sport i sport dlia vsekh. Problemy zdorov'ia, rekreacii, sportivnoj mediciny i reabilitacii, IV Mezhdunarodnyj nauchnyj kongress [Olympic sport and sport for all. Health problems, recreation, sports medicine and rehabilitation. IV International Scientific Congress], Kiev, 2000, pp. 385. (in Russian)

6. Kuzemko L.M. Razvitie fizicheskikh kachestv [Development of physical qualities], Chernigov, 2008, pp. 108-146. (in Russian)

7. Lisickaia T.S., Sidneva L.V. Aerobika [Aerobics]. Moscow, Federation aerobics, 2002, no.2, 232 p. (in Russian)

8. Bachinskaia N.V., Lapuga G.V. Uchebnye zaniatiia po aerobike [Teaching aerobics classes], Dnepropetrovsk, RVVDNU, 2011, 52 p. (in Russian)

9. Nosko N.A., Arkhipov A.A. [Quality motor as the main criteria of human motor function]. Vestnik Chernigovskogo nacional'nogo pedagogicheskogo universiteta. 2013, no.2, pp. 25-29. (in Russian)

10. Abdullin M.G., Gimranova L.V., Lopatina Z.F., Rylova E.V., Khalitova O.Iu. Ozdorovitel'naia aerobika [Improving aerobics], Ufa, Bashkir State Pedagogical University Publ., 2010, 64 p. (in Russian)

11. Rajcina L.P. [Sports and dance aerobics in high school]. Materialy IY mezhvuzovskoj nauchnoprakticheskoj konferencii «Fizicheskoe vospitanie i sport uchashchejsia molodezhi». [IY Interuniversity Scientific and Practical Conference "Physical education and sport students."]. Moscow, MGIU, 1998, pp. 12 - 13. (in Russian)

12. Rostovceva M.Iu. Povyshenie fizicheskoj rabotosposobnosti zhenshchin molodogo vozrasta sredstvami ritmicheskoj gimnastiki. Kand.dis. [Increase physical performance young women by means of rhythmic gymnastics. Kand.dis.], Malahovka, 1990, 24 p. (in Russian)

13. Sinica S.V., Shesterova L.E. Ozdorovitel'naia aerobika [Improving aerobics], Poltava, PNPU, 2011, 236 p. (in Russian)

14. Usachev V.I. Sposob kachestvennoj ocenki funkcii ravnovesiia [A method of qualitative evaluation of balance function]. Patent UA, no. 2175851, 2001. (in Ukrainian)

15. Khoroshukha M.F. Osnovy zdorov'ia iunykh sportsmenov [Health basics of young athletes], Kiev, NUBiP Ukraine, 2014, 722 p. (in Russian)

16. Shevchenko O.Iu. [Influence of improving aerobics on the functional state]. Olimpijs'kij sport $i$ sport dlia vsikh. 14 Mizhnarodnij naukovij kongres [14 International Scientific Congress. Olympic sport and sport for all], Kiev, 2010, pp. 639. (in Ukrainian) 
17. Céline Aguer, Olivier Gavarry, Yoann Gole, Alain Boussuges, Pierre Doyard, Guy Falgairette. A 5-month weight-reduction programme has a positive effect on body composition, aerobic fitness, and habitual physical activity of severely obese girls: A pilot evaluation study. Journal of Sports Sciences. 2010, vol.28, no.3, pp. 281-289.

18. Marcus Wayne Kilpatrick, Amy Lynn Bortzfield, Lisa Marie Giblin. Impact of aerobic exercise trials with varied intensity patterns on perceptions of effort: An evaluation of predicted, in-task, and session exertion. Journal of Sports Sciences. 2012, vol.30, no.8, pp. 825-832.

19. Melitta McNarry \& Andy Jones. The influence of training status on the aerobic and anaerobic responses to exercise in children: A review. Journal: European Journal of Sport Science. 2014, vol.14, no.1, pp. S57S68.

20. Stuart J.H. Biddle, Rock Braithwaite, Natalie Pearson. The effectiveness of interventions to increase physical activity among young girls: A meta-analysis. Preventive Medicine, 2014, no.62, pp. 119-131.

Information about the author:

Supilo I.P.: http://orcid.org/0000-0003-0911-0460; verdikt_aerodance@ rambler.ru; Chernihiv National Pedagogical University; Str. Polubotko Getman, 53, Chernigov, 14013, Ukraine.

Cite this article as: Shypulo I. P. Influence employment by improving aerobics on motor readiness of girls. Physical education of students, 2015,no.1,pp.67-71.http://dx.doi.org/10.15561/20755279.2015.0110

The electronic version of this article is the complete one and can be found online at: http://www.sportpedu.org.ua/html/arhive-e.html

This is an Open Access article distributed under the terms of the Creative Commons Attribution License, which permits unrestricted use, distribution, and reproduction in any medium, provided the original work is properly cited (http:// creativecommons.org/licenses/by/3.0/deed.en). 